\title{
Enhanced degradation of metalaxyl in agricultural soils of São Paulo State, Brazil ${ }^{(1)}$
}

\author{
Solange Papini(2) and Mara Mercedes de Andréa(2)
}

\begin{abstract}
This work investigated the effect of repeated applications on enhanced degradation of metalaxyl in two different agricultural soils used for cultivation of orange and lemon from Casa Branca and Itapetininga districts of São Paulo State, Brazil. Soil samples were collected from areas repeatedly treated with commercial ridomil 50GR for six successive years, and from other areas never exposed to this fungicide. At the laboratory, soil samples received a ${ }^{14} \mathrm{C}$-metalaxyl solution and its degradation was studied through radiometric techniques to measure biomineralization and recovery of extractable- and soil-bound products. Enhanced degradation was verified only in one soil, although partial degradation and mineralization of the fungicide were detected in both soils. The different rates and patterns of metalaxyl degradation in the soils were probably due to their different physical, chemical, and biological characteristics.
\end{abstract}

Index terms: fungicides, biodegradation, mineralization, soil deterioration.

\section{Degradação acelerada do metalaxil em solos agricultáveis do Estado de São Paulo}

\begin{abstract}
Resumo - Este trabalho investigou o efeito de repetidas aplicações de metalaxil no solo, sobre a degradação acelerada deste fungicida. O experimento foi realizado com dois tipos de solo provenientes dos municípios de Casa Branca e Itapetininga, SP, utilizados para plantações de laranja e limão. Amostras de ambos os solos foram coletadas de áreas repetidamente tratadas por seis anos consecutivos com aplicações do produto comercial ridomil 50GR, e de áreas nunca expostas a este fungicida. No laboratório, amostras dos solos receberam solução de ${ }^{14} \mathrm{C}$-metalaxil, e sua degradação foi avaliada a partir de estudos de biomineralização e recuperação de produtos extraíveis e ligados ao solo, utilizandose técnicas radiométricas. Os resultados demonstraram que ocorreu o fenômeno de degradação acelerada apenas em um dos tipos de solo, embora em ambos tenha-se detectado degradação parcial e mineralização do fungicida. As diferenças encontradas nas taxas e padrões de degradação entre os dois solos deveram-se, provavelmente, às características físicas, químicas e biológicas de cada um deles.
\end{abstract}

Termos para indexação: fungicidas, biodegradação, mineralização, degradação do solo.

\section{Introduction}

Metalaxyl [methyl D,L,N-(2,6-dimethylphenyl)$\mathrm{N}$-(2-methoxiacetyl) alaninate] is a systemic fungicide of the alaninate group (Worthing \& Hance, 1991) used to control Peronosporales fungi, which cause diseases in several crops, chiefly orange, lemon, po-

\footnotetext{
(1) Accepted for publication on January 31, 2000. Extracted from M.Sc. dissertation, presented by the first author to the Universidade de São Paulo (USP), São Paulo, SP.

(2) Instituto Biológico, Centro de Proteção Ambiental, Caixa Postal 12.898, CEP 04010-970 São Paulo, SP E-mail: spapini99@yahoo.com.br, andrea@biologico.br
}

tato, tomato, and tobacco (Cohen et al., 1979; Davidse et al., 1984; Sujkowski et al., 1995). As it is a biodegradable product, it can induce selection of the soil microbial population that is able to utilize the pesticide as nutrient and energy source. The selected microbial population would promote the fungicide dissipation from the environment. The repeated fungicide applications would improve this selection and enhance its degradation, as well as its dissipation. This phenomenon has been frequently detected with different pesticides and is known as enhanced degradation (Kaufman, 1974; Racke \& Coats, 1990; Charnay \& Fournier, 1993; Davis et al., 1994).

Pesticide enhanced degradation has deserved concern because it causes large and fast losses of the 
product, decreasing its efficacy, and leading to the need of increasing amounts to obtain the same result, which raises the costs.

Although the enhanced degradation had been detected with several pesticides in North-American and French soils (Bailey \& Coffey, 1986; Droby \& Coffey, 1991; Charnay \& Fournier, 1993; Cox et al., 1997), in Brazilian soils the phenomenon was observed only with parathion (Andréa et al., 1982).

The present work was conducted to study whether the repeated application of metalaxyl - as it is recommended and is being used for citrus crops - is promoting its enhanced degradation in different agricultural soils.

\section{Material and Methods}

The soils used in the experiments were collected in farms cultivated with orange and lemon at Casa Branca and Itapetininga, São Paulo State, Brazil. In both cities soil samples were collected in two different areas: one that received metalaxyl applications, as ridomil 50GR for six years, and another that was never treated with metalaxyl.

Some soil physicochemical characteristics were determined by the Department of Soil Sciences of Escola Superior de Agricultura Luiz de Queiroz at the University of São Paulo, and are presented in Table 1.

For the experiments, $25 \mathrm{~g}$ (dry-weight equivalent) of each soil were distributed in biometric flasks (Bartha \& Pramer, 1965) and moistened by addition of water to reach $40 \%$ of the soil's water maximum holding capacity, according to the International Organization for Standardization (1992).

Triplicate soil samples (25 g) from Casa Branca and Itapetininga previously treated or untreated with the fungicide received $30 \mu \mathrm{L}$ of an acetone solution containing $9.99 \mathrm{kBq}(0.27 \mu \mathrm{Ci})$ of ${ }^{14} \mathrm{C}$-metalaxyl, in the laboratory and were incubated for 63 days at $28^{\circ} \mathrm{C}$. Moisture was maintained during the period by regular weighing and addition of water when necessary. The metalaxyl uniformly ring labeled with $98 \%$ of purity was provided by CibaGeigy, Brazil.

The biomineralization (total degradation of the pesticide to $\mathrm{CO}_{2}$ and $\mathrm{H}_{2} \mathrm{O}$ ) was analysed through ${ }^{14} \mathrm{CO}_{2}$ production. The radiocarbon dioxide produced was collected after $14,28,42,56$, and 63 days of incubation in $10 \mathrm{~mL}$ of a $0.2 \mathrm{~mol} \mathrm{~L}^{-1} \mathrm{KOH}$ solution placed in the lateral arm of the biometric flasks. At each sampling time, the $\mathrm{KOH}$ solution was replaced by a newly prepared one, and $1 \mathrm{~mL}$ of the sampled solution was analysed by liquid scintillation spectrometry (LSC) after addition of the scintillation cocktail (Mesquita \& Ruegg, 1984) in a Packard Tri-Carb 1600TR instrument.

At the end of the 63-days period, the soil samples were extracted with $150 \mathrm{~mL}$ of ethyl acetate by mechanical shaking of the mixture during three hours. The mixture was left to decant and then filtered. One-mL aliquots of the extracts were mixed with the scintillation cocktail for organic solvent (Mesquita \& Ruegg, 1984) for determination of the ${ }^{14} \mathrm{C}$-extractable residues by LSC. The remaining extract of each sample was evaporated to dryness at $45^{\circ} \mathrm{C}$ in a roto-evaporator (Büchi 461) and the residues were resuspended in ethyl acetate for determination of the proportion of ${ }^{14} \mathrm{C}$-metalaxyl and its ${ }^{14} \mathrm{C}$-metabolites by thin layer chromatography (TLC) in silica gel-60 F254 (Merck) on aluminum sheets. The extracts were co-chromatographed with a metalaxyl standard, and ethyl acetate was used as the solvent system. All the radioactive zones in the chromatogram were detected by a radioscanner (LB 2723 Berthold). The identification of the different products was done by measurements of the Rf, which is the retention factor on the chromatogram $(\mathrm{Rf}=$ running distance of the compound/running distance of the solvent system). The total radioactivity was checked by cutting $1 \mathrm{~cm}$ zones of the plates and measuring their radioactivity by liquid scintillation counting.

When the radiocarbon recovered as ${ }^{14} \mathrm{CO}_{2}$ and ${ }^{14} \mathrm{C}$-extractable residues was less than $80 \%$, extracted soil samples were submitted to combustion to determine the ${ }^{14} \mathrm{C}$-bound residues present. The extracted soils were air-

Table 1. Selected characteristics of the soils at the 0 to $10 \mathrm{~cm}$ depth.

\begin{tabular}{|c|c|c|c|c|c|c|}
\hline \multirow[t]{3}{*}{ Soils } & \multicolumn{3}{|c|}{ Granulometric analysis } & \multirow[t]{3}{*}{ Textural class } & \multicolumn{2}{|c|}{ Chemical analysis } \\
\hline & Silt & Clay & Sand & & $\mathrm{pH}$ & O.M. \\
\hline & \multicolumn{3}{|c|}{ - } & & & $\left(\mathrm{g} \mathrm{kg}^{-1}\right)$ \\
\hline Casa Branca & 100 & 260 & 640 & Sandy Clay Loam & 3.9 & 18 \\
\hline Itapetininga & 120 & 550 & 330 & Clay & 5.0 & 33 \\
\hline
\end{tabular}


dried and $500 \mathrm{mg}$ samples were combusted in a Biological Oxidizer OX 600 (Harvey Instrument). The ${ }^{14} \mathrm{CO}_{2}$ produced was collected in monoethanolamine and scintillation cocktail (3:12 v/v) (Musumeci et al., 1982; Andréa et al., 1991). This mixture was then analysed by LSC to quantify the radioactivity.

\section{Results and Discussion}

The soil samples from Casa Branca never exposed to metalaxyl produced more ${ }^{14} \mathrm{CO}_{2}$ (maximum of $20.1 \%$ ) than the samples from the previously exposed area (maximum of $6.2 \%$ ). The soil from Itapetininga behaved in the opposite way, that is, samples from the treated area presented a biomineralization rate at least twice as high as that from the never exposed area (maximum of $26.9 \%$ and $11.5 \%$, respectively) (Figure 1).

As it was expected the ${ }^{14} \mathrm{C}$-extractable residues recovery was always higher in the samples where smaller biomineralization was detected (Table 2). The chromatograms of soil extracts showed mainly two extractable metabolites, besides metalaxyl $(\mathrm{Rf}=0.46)($ Table 3$)$. Higher amounts of the Rf 0.04-metabolite were found in samples where the biomineralization was also higher (Casa Branca untreated and Itapetininga treated areas), while greater amounts of the Rf 0.50-metabolite was formed in soil samples not previously treated with metalaxyl (Table 3). Therefore, the Rf 0.04-metabolite formation seems to be related with biomineralization activity, and the Rf 0.50-metabolite with previous fungicide treatments. The small amounts of the remaining percentage of radioactivity were spread on the chromatogram.

More than $45 \%$ of the radiocarbon was detected as ${ }^{14} \mathrm{C}$-bound residues in soil samples from Casa Branca untreated and Itapetininga treated areas (Table 2). In these soils and treatments higher microbial activity was detected, as indicated by the biomineralization test, as well as higher amounts of ${ }^{14} \mathrm{C}$-bound residues (CB untreated and ITA treated, Table 2). Besides the amount of ${ }^{14} \mathrm{C}$-bound residues (the compound itself or its partial degradation products) had been higher in these situations, the higher microbial activity also produced higher amounts of the Rf 0.04 extractable metabolite (CB untreated and ITA treated, Table 3), probably indicating a relation- ship between microbial activity and degradation. Different microorganisms are able to partial or complete degrade the metalaxyl (Bailey \& Coffey, 1986).

The inhibition of microbial activity caused by previous metalaxyl applications occurred in soil samples from Casa Branca repeatedly treated area, since their production of ${ }^{14} \mathrm{CO}_{2}$ was significantly smaller than that of the untreated one (Figure 1). Thus, a possible reduction of the microbial population by the selective action of the pesticide may have occurred. Besides, the repeated applications were also inhibiting biological or chemical processes that produce the Rf 0.50-metabolite, suggesting that former metalaxyl
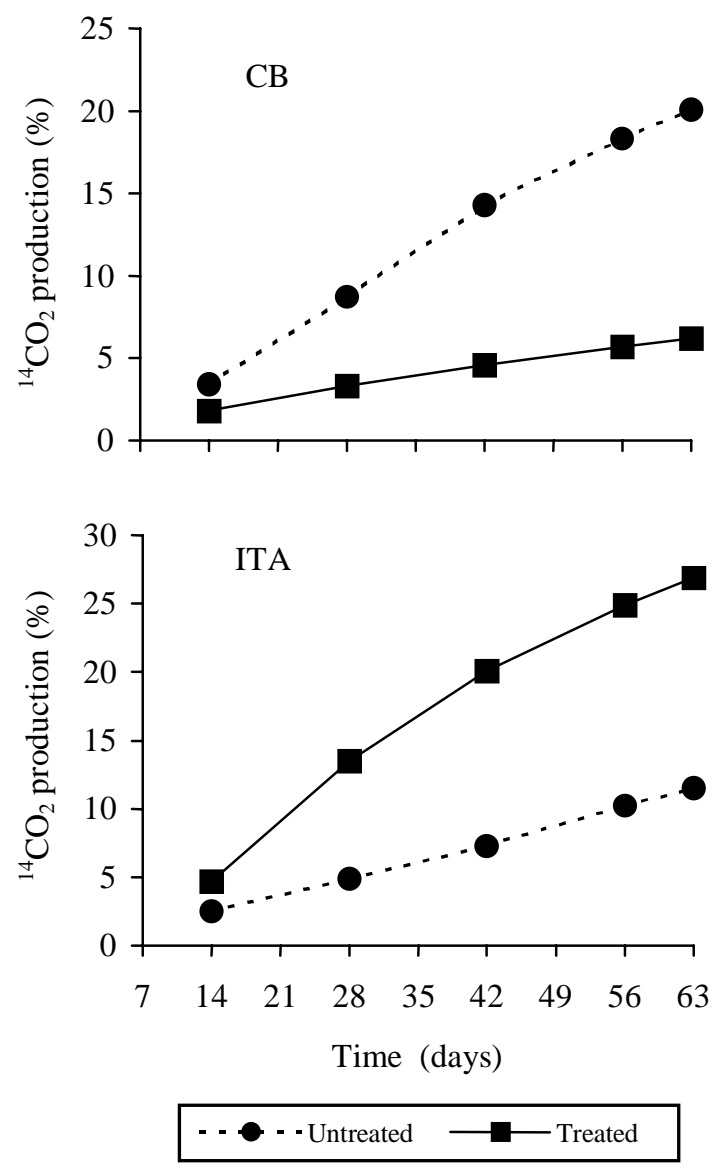

Figure 1. Production of ${ }^{14} \mathrm{CO}_{2}$ after ${ }^{14} \mathrm{C}$-metalaxyl application in the Casa Branca (CB) and in the Itapetininga (ITA) soils repeatedly treated or untreated with ridomil. 
applications had influenced negatively the microbial population responsible for this stage of degradation.

On the other hand, the ${ }^{14} \mathrm{CO}_{2}$ production in Itapetininga soil samples were significantly higher where there was a previous exposure to the fungicide. The microbial populations from this soil seem to be adapted to metalaxyl exposure, which turned them able to recognize and use the fungicide as nutrient and energy sources, making the enhanced degradation phenomenon evident.

The different results found in Casa Branca and Itapetininga soils indicate that physical and chemical characteristics of each soil may determine different composition and ability of the microbial community to degrade metalaxyl. It is known that the organic matter content is positively related to the amount and diversity of microorganisms, due to higher amounts of nutrients (Kaufman, 1974; Graham-Bryce, 1981). Although organic matter and clay might favor sorption of some substances, which make them less available to the microorganisms, organic matter also favors the growth of microorganisms on its solid surfaces, because it represents nutrient and energy sources. Thus, due to its physicochemical characteristics (higher clay and organic matter contents and $\mathrm{pH}$, Table 1), the Itapetininga soil has more favorable conditions to support living and active microorganisms and that might be able to use metalaxyl as a nutrient and energy source. The repeated metalaxyl applications may have stimulated or selected these microorganisms. However, in the more extreme environmental conditions of Casa Branca soil, the presence of microorganisms able to effectively degrade metalaxyl may not be as possible, and further, the repeated treatments might have resulted inhibitory for microbial population.

The $\mathrm{pH}$ is another important factor for determination of edaphic biodiversity. Alkalinity or acidity promote lower biodiversity than neutrality since fewer species tolerate extreme conditions. As the Casa Branca soil has lower $\mathrm{pH}$ than the Itapetininga soil (Table 1), lower diversity and number of microorganisms, and slower metabolism are expected for the Casa Branca soil.

Table 2. Radiocarbon-residues recovery after ${ }^{14} \mathrm{C}$-metalaxyl applications in the Casa Branca (CB) and Itapetininga (ITA) soils (percentage of total applied \pm standard deviations; $\mathrm{n}=3$ ).

\begin{tabular}{lrccc}
\hline Soils & \multicolumn{4}{c}{${ }^{14} \mathrm{C}$-recovery } \\
\cline { 2 - 5 } & ${ }^{14} \mathrm{CO}_{2}$ & ${ }^{14} \mathrm{C}$-extractable & ${ }^{14} \mathrm{C}$-bound & ${ }^{14} \mathrm{C}$-total \\
\hline CB untreated & $20.1 \pm 3.4$ & $44.8 \pm 2.1$ & $47.8 \pm 6.9$ & 112.7 \\
CB treated & $6.2 \pm 1.0$ & $79.1 \pm 11.7$ & - & 85.3 \\
ITA untreated & $11.5 \pm 1.8$ & $82.9 \pm 7.5$ & - & 94.4 \\
ITA treated & $26.9 \pm 6.2$ & $29.4 \pm 2.5$ & $46.4 \pm 8.9$ & 102.7 \\
\hline
\end{tabular}

Table 3. Main radiocarbon products in extracts of the Casa Branca (CB) and Itapetininga (ITA) soils (percentage of the extracted).

\begin{tabular}{lccc}
\hline Soils & \multicolumn{3}{c}{$\mathrm{Rf}^{(1)}$} \\
\cline { 2 - 4 } & 0.46 & 0.04 & 0.50 \\
& $\left({ }^{14} \mathrm{C}-\right.$-metalaxil $)$ & $\left({ }^{14} \mathrm{C}\right.$-metabolite $)$ & $\left({ }^{14} \mathrm{C}\right.$-metabolite $)$ \\
\hline CB untreated & 13 & 47 & 21 \\
CB treated & 35 & 38 & 15 \\
ITA untreated & 35 & 26 & 26 \\
ITA treated & 17 & 53 & 7 \\
\hline
\end{tabular}

(1) $\operatorname{Rf}$ (retention factor on the chromatogram) = running distance of the compound/running distance of the solvent system. 


\section{Conclusion}

The fungicide metalaxyl is enhanced degraded when some chemical ( $\mathrm{pH}$ and organic matter content) and physical (clay content) characteristics favor higher biological activity, as detected in Itapetininga soil.

\section{References}

ANDRÉA, M. L.; LORD, K. A.; BROMILOW, R. H.; RUEGG, E. F. Degradation of parathion by soil kept moist with and without repeated application. Environmental Pollution, Oxford, v. 27, p. 167-177, 1982.

ANDRÉA, M. L.; RUEGG, E. F.; TOMITA, R. Y.; MESQUITA, T. B. Dissipação do DDT ${ }^{14} \mathrm{C}$ em solo sob temperatura controlada e sob condições de campo. Pesquisa Agropecuária Brasileira, Brasília, v. 26, n. 10, p. 1691-1698, out. 1991.

BAILEY, A. M.; COFFEY, M. D. Characterization of microorganisms involved in accelerated biodegradation of metalaxil and metalachlor in soils. Canadian Journal of Microbiology, Ottawa, v. 32, p. 562-569, 1986.

BARTHA, R.; PRAMER, D. Features of a flask and method for measuring the persistence and biological effects of pesticides in soil. Soil Science, Baltimore, v. 100, p. 68-70, 1965.

CHARNAY, M. P.; FOURNIER, J. C. Microbial involvement in the enhancement of carbofuran degradation in some French soils. In: MANSOUR, M. (Ed.). Study and prediction of pesticides behavior in soils, plants and aquatic systems. Neuherberg : [s. n], 1993. p. 371-379.

COHEN, Y.; REVEUNI, M.; EYAL, H. The systemic antifungal activity of ridomil against Phytophthora infestans on tomato plants. Phytopathology, Saint Paul, v. 69, p. 645-649, 1979.

COX, L.; WALKER, A.; WELCH, S. J. Evidence for the accelerated degradation of isoproturon in soils. Pesticide Science, Chichester, v. 48, p. 253-260, 1997.

DAVIDSE, L. C.; GERRITSMA, O. C.; VELTHUIS, G. C. M. A differential basis of antifungal activity of acylalanine fungicides and structurally related chloroacetanilide herbicides in Phytophthora megasperma f. sp. medicaginis. Pesticide Biochemistry and Physiology, San Diego, v. 21, p. 301-308, 1984.

DAVIS, R. F.; JOHNSON, A. W.; WAUCHOPE, R. D. Accelerated degradation of phenemiphos and its metabolites in soil previously treated with phenemiphos. Journal of Nematology, Eaton Park, v. 25, p. 679-685, 1994.

DROBY, S.; COFFEY, M. D. Biodegradation process and the nature of metabolism of metalaxyl in soil. Annals of Applied Biology, Wellesbourne, v. 118, p. 543-553, 1991.

GRAHAM-BRYCE, I. G. The behavior of pesticides in soil. In: GREENLAND, D. J.; HAYES, M. H. B. (Ed.). The chemistry of soil processes. New York : J. Wiley, 1981. p. 621-670.

INTERNATIONAL ORGANIZATION FOR STANDARDIZATION (Geneva, Switzerland). ISO/DIS-11274. Geneva, 1992. 30 p.

KAUFMAN, D. D. Degradation of pesticides by soil microorganisms. In: GUENZI, W. D. (Ed.). Pesticides in soil and water. Madison : Soil Science Society of America, 1974. p. 133-135.

MESQUITA, R. B.; RUEGG, E. F. Influência de agentes tensoativos na detecção da radiação beta. Ciência e Cultura, São Paulo, v. 36, p. 446-450, 1984.

MUSUMECI, M. R.; FEICHTEMBERGER, E.; RUEGG, E. F.; CAMPACCI, C. A. Absorção e translocação sistêmica de metalaxil ${ }^{14} \mathrm{C}$ por plântulas de Citrus sinensis após aplicações em diferentes solos. Fitopatologia Brasileira, Brasília, v. 7, p. 397-400, 1982.

RACKE, K. D.; COATS, J. R. Enhanced biodegradation of insecticides in Midwestern corn soils. In: RACKE, K. D.; COATS, J. R. (Ed.). Enhanced biodegradation of pesticides in the environment. Washington : American Chemical Society, 1990. p. 82-97. (Symposium Series, 426).

SUJKOWSKI, L. S.; FRY, B. A.; POWER, R. J.; GOODWIN, S. B.; PEEVER, T. L.; HAMLEN, R. A.; FRY, W. E. Sensitive of Mexican isolates of Phytophthora infestans to chlorothalonil, cymoxanil and metalaxyl. Plant Disease, St. Paul, v. 79, p. 117-1120, 1995.

WORTHING, C. R.; HANCE, R. J. The pesticide manual. 9. ed. Surrey: The British Crop Protection Council, 1991. p. 554-555. 